\title{
Peran Bimbingan Pranikah melalui Badan Penasihatan Pembinaan dan Pelestarian Perkawinan (BP4) di Cijeungjing Ciamis
}

\author{
Ayi Ishak Sholih Muchtar \\ Institut Agama Islam Darussalam (IAID) Ciamis, Jawa Barat \\ Email: ayiishak.sholihmuchtar@gmail.com \\ Imas Umi Hani \\ Institut Agama Islam Darussalam (IAID) Ciamis, Jawa Barat \\ Yusuf Sabanda \\ Institut Agama Islam Darussalam (IAID) Ciamis, Jawa Barat
}

\begin{abstract}
ABSTRAK
Setiap orang yang memasuki pintu gerbang kehidupan berkeluarga melalui pernikahan, tentu menginginkan terciptanya suatu keluarga atau rumah tangga yang bahagia sejahtera lahir dan batin serta memperoleh keselamatan hidup di dunia dan diakherat nanti. Dari keluarga bahagia sejahtera inilah kelak akan terwujud masyarakat yang rukun, damai serta adil makmur material dan spiritual. Kehidupan keluarga dan masyarakat semacam inilah yang menjadi cita-cita dan tujuan pembangunan nasional. Agar cita-cita dan tujuan tersebut dapat terlaksana dengan sebaik-baiknya, maka suami isteri yang memegang peranan utama dalam mewujudkan keluarga bahagia sejahtera, perlu meningkatkan pengetahuan atau pendidikan tentang bagaimana membina kehidupan keluarga sesuai dengan tuntunan agama dan ketentuan hidup bermasyarakat, diharapkan setiap anggota keluarga khususnya suami isteri mampu menciptakan stabilitas kehidupan rumah tangga yang penuh dengan ketentraman dan kadamaian.
\end{abstract}

\begin{abstract}
Everyone who enters the gate of married life through marriage, certainly wants the creation of a family or a happy, prosperous and spiritual home and to obtain the salvation of life in the world and later in life. From this happy, prosperous family will come to be a harmonious, peaceful and just society of material and spiritual prosperity. This family and community life is the goal and goal of national development. In order for these ideals and goals to be carried out with the best, then the husband and wife who play a major role in creating a happy family prosperous, need to increase knowledge or education about how to foster family life in accordance with religious guidance and the provision of community life, expected every
\end{abstract}


family member especially the husband and wife able to create the stability of household life filled with tranquility and peace.

Keywords: Wedding Education, Happy Family.

\section{PENDAHULUAAN}

Setiap orang yang memasuki pintu gerbang kehidupan berkeluarga melalui perkawinan, tentu menginginkan terciptanya suatu keluarga atau rumah tangga yang bahagia sejahtera lahir dan batin serta memperoleh keselamatan hidup di dunia dan diakherat nanti.Dari keluarga bahagia sejahtera inilah kelak akan terwujud masyarakat yang rukun, damai serta adil makmur material dan spiritual.

Kehidupan keluarga dan masyarakat semacam inilah yang menjadi cita-cita dan tujuan pembangunan nasional. Agar cita-cita dan tujuan tersebut dapat terlaksana dengan sebaik-baiknya, maka suami isteri yang memegang peranan utama dalam mewujudkan keluarga bahagia sejahtera, perlu meningkatkan pengetahuan dan pengertian tentang bagaimana membina kehidupan keluarga sesuai dengan tuntunan agama dan ketentuan hidup bermasyarakat, diharapkan setiap anggota keluarga khususnya suami isteri mampu menciptakan stabilitas kehidupan rumah tangga yang penuh dengan ketentraman dan kadamaian. Stabilitas kehidupan rumah tangga inilah yang merupakan modal dasar bagi berbagai upaya pembinaan keluarga bahagia dan sejahtera.

Perkawinan merupakan salah satu sunnatullah yang umum berlaku pada semua makhluk Allah, baik pada manusia, hewan maupun tumbuhtumbuhan. Semua yang diciptakan oleh Allah adalah berpasang-pasangan dan berjodoh-jodohan sebagaimana berlaku pada makhluk yang paling sempurna, yakni manusia.

Dalam surat Al-Dzariyat ayat 49 disebutkan:

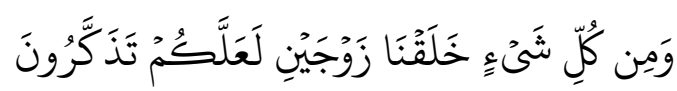

“Dan segala sesuatu Kami ciptakan berpasang-pasangan supaya kamu mengingat kebesaran Allah" (Q.S. Al-Dzariyat, 51: 49)

Perkawinan dalam syariat Islam bukan sekedar formalitas, karena perkawinan itu bertujuan untuk membentuk keluarga yang sakinah mawadahwarahmah dan untuk mendirikan salah satu amanah suci dari Ilahi juga akad nikah itu bertujuan untuk mempertemukan dua pribadi yang sama-sama bermartabat kemanusiaan dalam ikatan suami istri yang mengandung ketentuan tentang hak dan kewajiban yang harus dipenuhi secara timbal balik (Djaelani, 1995: 52). 
Pada umumnya semua pasangan suami istri mendambakan keluarga yang sakinahmawadahwarahmah seperti ditegaskan dalam Kompilasi Hukum Islam. Pasal 2 yaitu Perkawinan menurut Hukum Islam adalah pernikahan yaituakad yang sangat kokoh (Mitsaaqon Ghalidhon) untuk mentaati perintah Allah dan pelaksanaannya merupakan ibadah.

Keluarga sakinah merupakan keluarga idaman dan harapan bagi setiap umat Islam. Keluarga sakinah adalah potret keluarga bahagia menurut Islam.Dalam sebuah hadits, dijelaskan bahwa terbentuknya keluarga sakinah diawali oleh sebuah cita-cita dantujuan awal anda menikah.

Hal ini sebagaimana dijelaskan dalam hadits Rasulullah Saw. yang artinya

Barang siapa yang melihat wanita karena kemegahannya, tidak ditambahkan oleh Allah kepadanya, kecuali kehinaan.Barang siapa yang mengawini seseorang karena hartanya, tidak ditambahkan kepadanya, kecuali kefakiran.Barang siapa mengawini seorang perempuan karena melihat silsilah keturunannya(ningrat), tidak ditambahkan kepadanya oleh Allah, kecuali rendah diri (minder). Barang siapa mengawini seorang perempuan hanya untuk menutup matanya dari yang haram, atau untuk menyambung silahturahmi, niscaya Allah melimpahkan keberkahannya kepada wanita itu, dan sebaliknya (HR, Ibnu Majah dan Ibnu Hibban).

Dalam Undang-Undang Perkawinan Nomor 1 Tahun 1974 dan Kompilasi Hukum Islam batas usia pernikahan juga diatur, karena hal tersebut maka usia perkawinan harus jadi perhatian.Keluarga merupakan unit terkecil pembentukan masyarakat. Tujuan Islam dalam pembentukan keluarga adalah menciptakan kesejahteraan dan penuh rasa cinta kasih dan sayang.

Keberadaan Badan Pembinaan Penasehatan dan Pelestarian Perkawinan (BP4) di Kecamatan sangatlah perlu karena sangat membantu terhadap tugas Kantor Urusan Agama dan Badan Pembinaan Penasehatan dan Pelestarian Perkawinan berperan penting dalam memberikan pembinaan terhadap pasangan calon pengantin. Dalam pasal 1 anggaran dasar Badan Pembinaan dan Pelestarian Perkawinan disebutkan bahwa organisasi ini bernama Badan Penasehatan, Pembinaan dan Pelestarian Perkawinan disingkat menjadi BP4 atau disebut Badan Penasehat Perkawinan.

Peraturan-peraturan yang mengatur Badan Pembinaan Penasehatan dan Pelestarian Perkawinan diantaranya Peraturan Direktur Jenderal Bimas Islam Kementrian Agama RI No: Dj.II/491 tahun 2009, Keputusan Menteri Agama Nomor: 3 Tahun 1999, Keputusan Direktur Bimbingan masyarakat 
Islam dan Urusan Haji No: D/71/1999. BP4 juga memiliki dokumen penting yaitu: Data pembinaan calon pengantin, data pembinaan mediasi perceraian, data keluarga sakinah.

Dalam pedoman BP4 Kemenag Ciamis menyebutkan bahwa keluarga sakinah adalah keluarga yang di bina atas perkawinan yang sah, mampu memenuhi hajat spiritual material secara layak dan seimbang, diliputi suasana kasing sayang antara anggota keluarga dan lingkungannya dengan selaras, serasi, serta mampu mengamalkan, menghayati dan memperdalam nilai-nilai keimanan, ketakwaan dan akhlaq Mulia. Dengan demikian Badan Penasehatan Pembinaan dan Pelestarian Perkawinan Kecamatan Cijeungjing berupaya memaksimalkan programnya dalam hal menciptakan keluarga sakinah. Badan Penasehatan Pembinaan dan Pelestarian Perkawinan memiliki azas dan tujuan, yang berdasarkan Islam dan berazaskan pancasila.

\section{KAJIAN TEORETIS}

\section{Badan Penasihatan Pembinaan dan Pelastarian Perkawinan (BP4)}

Kata "upaya atau peranan" diartikan sebagai bagian dari tugas utama yang harus dilaksanakan (Anonimous, 1990: 667). Upaya atau peranan merupakan salah satu terori dalam sosiologi. Dafid Berry (2003) menjelasakan pemikiran para sarjana sosiologi tentang manusia di dalam masyarakat diungkapkan dalam konsep peranan. Bagi sarjana sosiologi manusia dilihat sebagai pelaku dari upaya atau peranan sosial.

Kata "upaya atau peranan" yang dihubungkan dengan Penasehat Pembinaan dan Pelestarian Perkawinan (BP4) maksdunya adalah untuk mengetahui seperangkat tugas yang harus dilaksanakan oleh BP4 dalam memberikan bimbingan dan penngarahan akan pentingnya keutuhan keluarga dan sejauh mungkin hindarkan perceraian.

Penasihatan perkawinan adalah suatu pelayanan sosial mengenai masalah keluarga, khususnya hubungan suami istri, tujuan yang hendak ialah tercapainya situasi yang menyenangkan dalam hubungan suami istri, sehingga dengan situasi yang menyenangkan tersebut suatu keluarga dapat mencapai kebahagiaan.

"Penasihatan perkawinan adalah suatu proses jadi memerlukan waktu yang relatif lama, tidak hanya sekali saja. Mungkin untuk sepasang suami istri (keluarga membutuhkan watu beberapa tahun, tetapi mungkin juga ada yang hanya beberapa bulan saja. Hal ini tergantung pada kondisi masing-masing keluarga. (Anonimous, 2002: 12).

Penasihatan perkawinan secara terminologi menurut BP4 (1985: 4) adalah upaya pemberian pelajaran (bimbingan) tentang perkawinan bagi mereka yang akan melangsungkan perkawinan khususnya calon pengantin. 
Pengertian ini sesuai dengan penjelasan dalam buku pedoman penasihatan perkawinan (1985: 4) yang menjelaskan bahwa yang dimaksud dengan penasihatan adalah upaya penasihatan atau bimbingan yang dilakukan perseorangan atau badan kepala seseorang yang membutuhkan nasihat, baik pria maupun wanita, remaja ataupun dewasa yang akan melangsungkan pernikahan.

a. Peraturan-peraturan yang mengatur tentang BP4

Peraturan Jenderal Bimas Islam Kementrian Agama RI No: DJ.II/491 tahun 2009, Keputusan Menteri Agama No: 3 Tahun 1999, Keputusan Direktur Bimbingan Masyarakat Islam dan Urusan Nomor: D/71/1999 keputusan Konperensi Departemen Agama di Tretes Jawa Timur tanggal 2531, maka disatukan organisasi tersebut dengan nama Badan Penasehat Perkawinan nomor 85 Tahun 1961, dan berdasarkan keputusan Menteri Agama Nomor 30 tahun 1977 tentang penegasan pengakuan BP4 sebagai satu-satunya badan penunjang sebagai tugas Kementrian Agama dalam bidang Penasehatan Perkawinan Perselisihan rumah tangga dan Perceraian, maka kepanjangan BP4 menjadi Badan Penasehatan Perkawinan, Perselisihan dan Perceraian.

\section{Konsep Perkawinan}

Pengertian perkawinan adalah suatu kegiatan yang sakral antara seorang pria dengan seorang wanita yang diawali dengan suatu akad yang sangat kuat (mitsaqon gholidhon) yang dihadiri oleh dua orang saksi dan ijab dilaksanakan oleh seorang wali dari calon pengantin istri dan kabul atau penerimaan oleh calon pengantin pria yang pelaksanaanya merupakan Sunnah Rasul.

Allah menciptakan semua makhluk serba berpasangan demikian juga manusia diciptakan berpasangan jadi berkeluarga adalah pitrah hidup. Menurut Undang-Undang Republik Indonesia tentang Perkawinan Nomor 1 Tahun 1974 pasal 1. Perkawinan ialah ikatan lahir batin antara seorang pria dengan seorang wanita sebagai suami istri dengan tujuan membentuk keluarga (Rumah Tangga) yang bahagia dan kekal berdasarkan Ketuhanan Yang Maha Esa. Tujuan Islam dalam pembentukan keluarga adalah menciptakan kesejahteraan dan penuh rasa cinta kasih dan sayang untuk mendapatkan ketentraman.

Menurut Djaelani (1995: 10) tujuan utama perkawinan ialah untuk memperoleh keturunan yang banyak agar planet bumi ini dipenuhi dan dimakmurkan oleh umat islam, umat yang telah diangkat oleh Allah sebagai Khalifah agar mampu menerapkan hukum-hukum Allah agar semua manusia tunduk dan patuh hanya kepada Allah, dalam pandangan beliau kehadiran anak merupakan segala-galanya dan merupakan suatu keharusan demi kejayaan Agama Islam dan Rosul memuji wanita yang banyak anak. 
Sebagaimana Firman Allah dalam Al-Qur'an surat Al Ruum ayat 21:

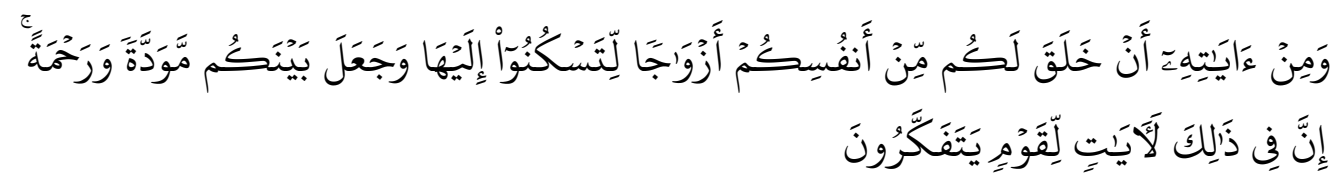

Dan di antara tanda-tanda kekuasaan-Nya ialah Dia menciptakan untukmu isteri-isterimu dari jenismu sendiri, supaya kamu cenderung dan merasa tenteram kepadanya, dan dijadikan-Nya diantaramu rasa kasih dan sayang. Sesungguhnya pada yang demikian itu benar-benar terdapat tanda-tanda bagi kaum yang berfikir (QS. Al Rum, 30: 21).

Perkawinan dilihat dari segi aspek dibagi tiga bagian yaitu:

1) Perkawinan dilihat dari segi hukum

Dipandang dari segi hukum, perkawinan itu merupakan suatu perjanjian yang sangat kokoh hingga dapat dikemukakan sebagai alasan untuk mengatakan bahwa perkawinan itu merupakan suatu perjanjian disebabkan karena adanya: (a) Cara mengadakan ikatan perkawinan telah diatur terlebih dahulu yaitu dengan akad nikah dan dengan syarat dan rukun tertentu. (b) Cara memisahkan atau memutuskan ikatan perkawinan juga telah diatur sebelumnya yaitu dengan prosedur talak, kemudian fasakh, siqoq dan sebagainya. (c) Perkawinan dilihat dari segi sosial

Dalam masyarakat setiap bangsa ditemui suatu penilaian yang umum, ialah bahwa orang yang berkeluarga atau pernah berkeluarga mempunyai kedudukan yang telah dihargai dari mereka yang belum atau tidak kawin.

Menurut pandangan Hukum Agama perkawinan dianggap suatu acara yang suci, yang kedua belah pihak dihubungkan menjadi pasangan suami istri atau saling minta menjadi pasangan hidupnya untuk mengharapkan keridhoan Allah Dari sebuah perkawinan maka terbentuklah sebuah keluarga yang merupakan unsur terkecil namun utama di masyarakat. Sedangkan keluarga itu sendiri terbentuk dari seorang laki-laki dan seorang perempuan yang telah mengikatkan diri dalam suatu institusi perkawinan. (Sayuti Thalib, 1986: 47-48).

Seperti dikemukakan dalam hadits nabi dalam kitab Bulugul Maram, Bab Nikah hadits ke 955:

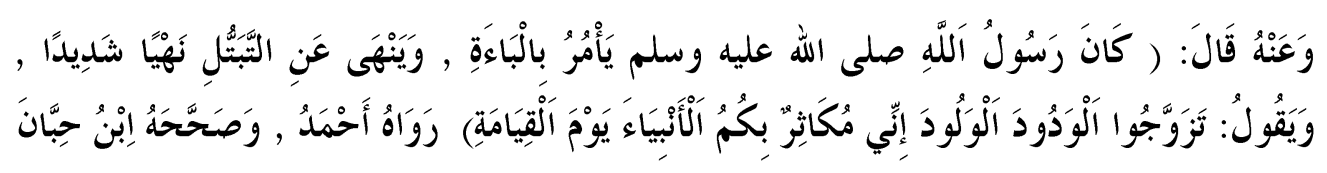

Dan dari Anas bin Malik RA bersabda Rasulullah SAW, Rosul memerintahkan kita untuk menikah dan dilarang keras membujang, beliau juga bersabda, nikahilah oleh kalian wanita yang subur (bisa 
banyak melahirkan keturunan) maka sesungguhnya aku bangga dengan banyaknya sebagai umatku pada hari kiamat dihadapan para Nabi-nabi (Ibnu Hajar Al-Asqalani, 1984: 20).

\section{Tujuan Perkawinan}

Tujuan perkawinan menurut agama islam ialah untuk memenuhi petunjuk agama dalam rangka mendirikan keluarga yang harmonis, sejahtera dan bahagia. Harmonis dalam menggunakan hak dan kewajiban anggota keluarga; sejahtera artinya terciptanya ketenangan lahir dan batin disebabkan terpenuhinya keperluan hidup lahir dan batinnya, sehingga timbullah kebahagiaan, yakni kasih sayang antar anggota keluarga.

Manusia diciptakan Allah SWT mempunyai naluri manusiawi yang perlu mendapat pemenuhan. Dalam pada itu manusia diciptakan oleh Allah SWT untuk mengabdikan dirinya kepada khaliq penciptanya dengan segala aktivitas hidupnya. Pemenuhan naluri manusiawi manusia yang antara lain keperluan biologisnya termasuk aktivitas hidup, agar manusia menuruti tujuan kejadiannya, Allah SWT mengatur hidup manusia dengan aturan perkawinan.

Jadi aturan perkawinan menurut islam merupakan tuntunan agama yang perlu mendapat perhatian, sehingga tujuan melangsungkan perkawinan pun hendaknya ditujukan untuk memenuhi petunjuk agama. Sehingga kalau diringkas ada dua tujuan orang melangsungkan perkawinaan ialah memenuhi nalurinya dan memenuhi petunjuk agama.

Menurut Imam Al-Ghazali dalam ihyanya tentang faedah melangsungkan perkawinan, maka tujuan perkawinan itu dapat dikembangkan menjadi lima yaitu: (a) Mendapatkan dan melangsungkan keturunan. (b) Memenuhi hajat manusia untuk menyalurkan syahwatnya dan menumpahkan kasih sayangnya. (c) Memenuhi panggilan agama, memelihara diri dari kejahatan dan kerusakan. (d) Menumbuhkan kesungguhan untuk bertanggung jawab menerima hak serta kewajiban, juga bersungguh-sungguh untuk memperoleh harta kekayaan yang halal. (e) Membangun rumah tangga untuk membentuk masyarakat yang tenteram atas dasar cinta dan kasih sayang.

\section{Dasar Perkawinan}

Berdasarkan pada undang-undang Perkawinan No. 1 tahun 1974 pasal 2 ayat 1, perkawinan yang telah dilaksanakan suami-istri menurut agama bukan islam itu tetap sah, karena kedua mempelai saat itu masih beragama kristen. Namun setelah pasangan suami-isteri masuk islam, perkawinan pertamanya menjadi tidak sah menurut hukum perkawinan islam. Berdasarkan pada Undang-Undang Perkawinan No. 1 tahun 1974 pasal 2 yang menyebutkan: (1) Perkawinan adalah sah, apabila dilakukan menurut hukum masing-masing agamanya dan kepercayaanya itu. (2) Tiap- 
tiap perkawinan dicatat menurut peraturan perundang-undangan yang berlaku. (Anonimous, 1987:6)

Hikmah perkawinan menurut ulama fiqih mengatakan diantaranya adalah untuk menyakurkan naluri seksual secara sah dan benar dan juga untuk menyalurkan naluri kebapaan atau keibuan, memupuk rasa tanggung jawab dalam rangka memelihara dan mendidik anak, membagi rasa tanggung jawab antara suami istri yang selama ini dipikul masing-masing pihak, menyatukan keluarga masing-masing pihak hingga hubungan silahturahmi semakin kuat dan terbentuk keluarga baru yang lebih banyak dan juga hikmah yang terakhir adalah memperpanjang usia. (Anonimous, 2009: 12).

\section{Konsep Keluarga Sakinah}

Istilah keluarga sakinah merupakan konsep berkeluarga ideal umat Islam yang sudah tidak asing lagi. Istilah ini dibentuk oleh dua suku kata, yakni kata keluarga dan kata sakinah. Secara etimologi, keluarga dalam Kamus Besar Bahasa Indonesia mempunyai artian: Ibu, bapak dengan anakanaknya; orang seisi rumah yang menjadi tanggungan, batih. (Anonimous, 1990:667).

Pengertian lain dari keluarga secara terminologi, seperti didefinisikan oleh Ismail Widjaja yakni suatu bentuk ikatan yang syah antara laki-laki dengan perempuan melalui ikatan perkawinan. Ikatan perkawinan tersebut kemudian melahirkan keturunan yang secara hukum menjadi tanggungjawab suami dan istri atau ibu dan bapak dalam membina dan mengembangkan mereka. (Widjaja, 1987:125).

Undang-undang Nomor 1 tahun 1974 tentang perkawinan pada pasal 1 disebutkan: "Perkawinan ialah ikatan lahir batin antara seorang lakilaki dan seorang perempuan sebagai suami-isteri dengan tujuan membentuk keluarga atau rumah tangga yang bahagia dan kekal berdasarkan agama dan kepercayaannya masingmasing. (Widjaja, 1987:99).

Buku panduan KB. Mandiri (Widjaja, 1987:125), menguraikan mengenai tujuan dan alasan mengapa sesorang ingin berkeluarga, beberapa diantaranya antara lain: (a) Ingin dilayani oleh suami atau isteri, baik pelayanan yang bersifat kebutuhan lahiriah maupun batiniah. (b) Ingin mempunyai keturunan guna meneruskan kelangsungan hidup generasinya. (c) Untuk merencanakan kehidupan masa depan yang lebih baik. (d) Adanya anjuran dari agama.

Sejumlah tujuan dan alasan seseorang ingin berkeluarga seperti tersebut diatas, dapat diambil rumusan yang sederhana mengenai tujuan berkeluarga yaitu: "berkeluarga adalah untuk mengembangkan cinta kasih, kepribadian, kebutuhan keturunan, juga termasuk ingin bekerjasama dan merencanakan masa depan yang lebih baik. 
Istilah sakinah secara etimologis disebutkan sebanyak enam kali dalam Al-quran seperti tertulis pada buku ensiklopedi Islam (Ensiklopedia, 1991:201). Pengungkapan Al-Qur'an itu jelas disebutkan bahwa sakinah itu memiliki arti ketentraman, ketenangan, kedamaian, rahmat, dan tuma'ninah yang berasal dari Allah Seperti terurai pada QS. Al-Baqarah ayat 248:

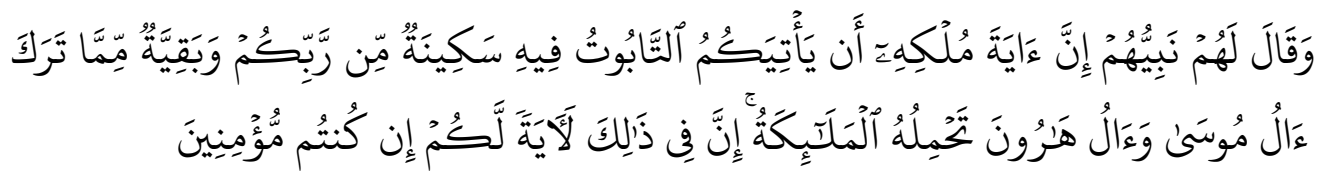

Dan nabi mereka mengatakan kepada mereka: "Sesungguhnya tanda ia akan menjadi raja, ialah kembalinya tabut kepadamu, di dalamnya terdapat ketenangan dari Tuhanmu dan sisa dari peninggalan keluarga Musa dan keluarga Harun; tabut itu dibawa malaikat. Sesungguhnya pada yang demikian itu terdapat tanda bagimu, jika kamu orang yang beriman.

Secara terminologis ungkapan tentang sakinah dalam Al-Qur'an muncul beberapa pengertian. Ali bin Muhammad al-Jurjani (w.816 H /1413 M), ahli pembuat kamus-kamus ilmiah, menyebutkan bahwa sakinah adalah adanya ketentraman dalam hati pada saat datangnya sesuatu yang tak diduga, dibarengi satu nur (cahaya) dalam hati yang memberi ketenangan dan ketentraman dalam hati pada yang menyaksikannya dan merupakan pokok 'ain al-yaqin (keyakinan berdasarkan penglihatan). Pasal 3 KHI (Kompilasi Hukum Islam) disebutkan bahwa: "perkawinan bertujuan untuk mewujudkan kehidupan rumah tangga yang sakinah (tentram), mawaddah (penuh cinta) dan rohmah (penuh kasih sayang)." (Muttaqin, et all, 1993:67).

Pengertian secara epistemologis pada penelitian ini, keluarga sakinah memiliki makna sekelompok orang yang terdiri atas Ibu,bapak beserta anakanaknya, yang berupaya untuk mengarungi bahtera kehidupan rumah tangga dengan diliputi perasaan tenang, tentram, bahagia dan tidak gelisah berdasar atas tuntunan agama. Keluarga sakinah yang mawaddah (penuh cinta) dan warrohmah (penuh kasih sayang), bukan suatu hal yang mudah, tetapi sangat sulit dan benar-benar harus dicari untuk dapat mencapai tujuan kesana. Ibaratnya akan banyak duri dan batu sandung yang harus disingkirkan terlebih dahulu.

Ketika hati kita sudah terbuka dan siap menerima kebenaran, maka hati bisa memberikan sinyal positif kepada anda sebagai ataupun istri. Jika perintah positif diamini oleh akal maka akal akan menyuruh seluruh badan kita untuk berperilaku positif. Kesimpulannya, keluarga sakinah, mawadah, warahmah tercermin dalam aktivitas sehari-sehari dan sikap istri kepada suami maupun sebaliknya. Sehingga, aktivitas dalam rumah tangga melahirkan suatu kedamaiaan dan ketentraman dalam menjalaninya. 
Demikian juga dengan tetangga dan masyarakat sosial lainnya. (Imam, 2013: 19).

Nampaknya pembentukan keluarga tetap relevan di abad 21, karena ia merupakan tuntutan fitrah manusia, hanya saja keluarga seperti apa yang mampu bertahan di era globalisasi.

Keluarga sakinah yang penuh keindahan tak terjadi secara singkat, melainkan melalui proses yang memiliki tahapan-tahapan. Ada tiga tahap yang mesti dilalui untuk dapat meraih keluarga sakinah: Pertama, tahap Pertama Qobla Zawaj (Proses Sebelum Pernikahan): (a) Unggul dalam Agama. (b) Berasal dari keturunan yang baik. (c) Mengutamakan orang jauh. (d) Mengutamakan gadis. (e) Mengutamakan wanita yang banyak anak. Kedua, tahap ke dua Zawaj (Pernikahan). Dalam tahap ini pasangan suami istri, harus melakukan ihsanul mumaal (baik dalam gaul). Hal ini diopersionalkan dengan pengetahuan dan melaksanakan kewajiban atau fungsi masing-masing (sebagai suami atau istri) dengan di landasi niat karena Allah semata.

Adapun kewajiban seorang istri terhadap suaminya adalah

1) Taat.

2) Memberikan sambutan yang menyenangkan .

3) Qanaah dan berterima kasih terhadap pemberian suami.

4) Izin bila hendak bepergian.

5) Selalu berusaha berebut keridhaan dan kasih sayang suaminya.

6) Memperlakukan istri dengan baik dan sopan.

7) Memperlihatkan muka yang manis dan penuh kasih sayang.

8) Memberi nafkah yang cukup.

9) Memberi nasihat.

10) Mendidik istri

11) Membantu pekerjaan istri

Ketiga, tahap Ketiga Ba'da Zawaj (Setelah Pernikahan). Pada fase ini pasangan suami istri dihadapkan pada sebuah pekerjaan yang besar, yaitu tarbiyatul aulad (mendidi anak) agar mampu menjadi generasi Rabbi Rodiya. Sebuah generasi yang menjadi penyejuk mata buat kedua orang tuanya, dan umat sekalian.

Adapun tahap dalam tarbiyatul aulad adalah: (a) Memperdengarkan azan dan iqomat pada bayi yang baru lahir. (b) Mentahnik. (c) Mencukur rambut. (d) Memberi nama

\section{Kaitan Sakinah, Mawaddah dan Warrahmah}

Terminologi Sakinah sebagaimana telah dijelaskan pada awal tulisan ini mempunyai makna tenang tentram, dan tidak gelisah. Sedang terminologi dari Mawaddah yakni penuh cinta, dan terminologi warrahmah memiliki artian kasih sayang. 
Tujuan dalam penelitian kali ini tidaklah cukup dalam mengetahui term sakinah saja,dengan perasaan tenang. Mawaddahlah yang menjembatani agar cita-cita kehidupan keluarga menjadi penuh cinta dalam anggota keluarga muslim, yang kemudian didasari oleh warrahmah perasaan kasih sayang yang tulus terhadap sesama dalam mengarungi bahtera rumah tangga.

Kewajiban yang paling utama yaitu masing-masing suami istri mengetahui fungsi tugas dan kewajiban, baik kewajiban bersama maupun kewajiban masing-masing antara suami istri. Undang-Undang Perkawinan Nomor 1 tahun 1974 pasal 30 menyatakan: Suami istri memikul kewajibankewajiban yang luhur untuk menegakkan rumah tangga yang menjadi sendi dasar dari susunan masyarakat. Oleh karena itu suami istri wajib: (a) Saling mencintai, saling menghormati dan memberi bantuan lahir batin yang satu kepada yang lain. (b) Suami wajib melindungi istrinya dan memberikan segala keperluan hidup berumah tangga sesuai dengan kemampuan. (c) Istri wajib mengatur rumah tangga sebaik-baiknya.

Suami wajib mempergunakan haknya secara hak dan dilarang menyalahgunakan haknya, disamping itu dia wajib menunaikan kewajibannya dengan sebaik-baiknya. Apabila suami isteri telah melaksanakan kewajian masing-masing, maka hak suami isteri juga bisa didapat dan terwujudlah tujuan menuju kearah ketentraman hidup dan kesenangan jiwa masing-masing, kebahagian lahir dan batin secara bersamaan.

Apa yang menjadi kewajiban suami terhadap isteri adalah merupakan hak bagi isteri terhadap suami dan begitu pula sebaliknya. Apa yang menjadi kewajiban isteri terhadap suami merupakan hak suami terhadap isteri. Mengenai hak suami akan diuraikan pada bagian kewajiban isteri terhadap suaminya. Adapun kewajiban suami terhadap isterinya ada dua macam, yaitu pertama kewajiban yang bersifat materil, kedua kewajiban yang bersifat materil. Kewajiban suami yang bersifat materil antara lain mahar dan nafkah, serta menjaga isteri dengan baik

Oleh karena itu, hak-hak suami yang wajib dipenuhi hanya merupakan hak bukan kendaan sebab menurut Hukum Islam misteri tidak boleh dibebani kewajiban kebandaan yang diperlukan untuk mencukupi kebutuhan hidup keluarga. Hak-hak suami adalah hak ditaati mengenai halhal yang menyangkut hidup perkawinan dan hak memberi pelajaran kepada isteri dengan cara yang baik dan layak dengan kedudukan suami isteri. Firman Allah, dalam Al-Qur'an surat An-Nisa ayat 34 yaitu:

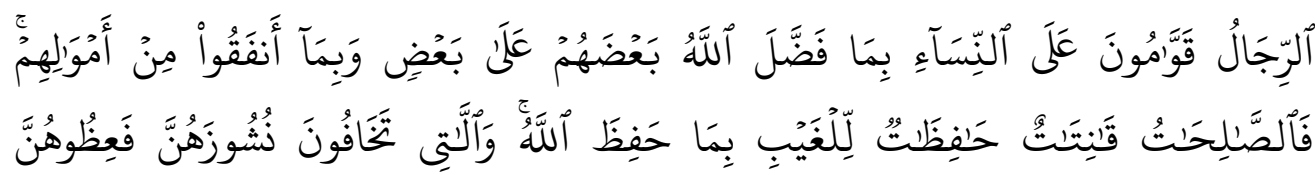




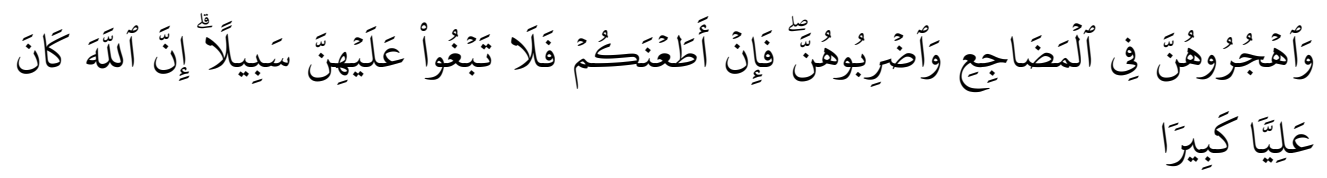

Kaum laki-laki itu adalah pemimpin bagi kaum wanita, oleh Karena Allah Telah melebihkan sebahagian mereka (laki-laki) atas sebahagian yang lain (wanita), dan Karena mereka (laki-laki) Telah menafkahkan sebagian dari harta mereka. sebab itu Maka wanita yang saleh, ialah yang taat kepada Allah lagi memelihara diri ketika suaminya tidak ada, oleh Karena Allah Telah memelihara (mereka). wanita-wanita yang kamu khawatirkan nusyuznya, maka nasehatilah mereka dan pisahkanlah mereka di tempat tidur mereka, dan pukullah mereka. Kemudian jika mereka mentaatimu, Maka janganlah kamu mencari-cari jalan untuk menyusahkannya. Sesungguhnya Allah Maha Tinggi lagi Maha besar.

Dari kandungan An-Nisa ayat 34 tersebut yang pertama dapat diperoleh ketentuan bahwa kewajiban suami dalam memimpin isteri itu tidak akan terselenggara dengan baik apabila isteri tidak taat kepada suami sebagai pemimpin mereka. Pengertian taat disini adalah: (a) Isteri supaya bertempat tinggal bersama suami di rumah yang telah disediakan. (b) Taat kepada perintah-perintah suami yang sesuai dengan ketentuan syri'at. (c) Tidak keluar rumah kecuali denga izin suami. (d) Tidak meneriam masuknya seseoorang (laki-laki) tanpa izin suami.

Kedua dari kandungan ayat tersebut, mengajarkan apabila terjadi kekhawatiran suami bahwa isterinya membangkang (nusyuz), hendaklah diberi nasehat secara baik-baik, apabila dengan nasehat pihak isteri belum juga mau taat, hendaklah suami berpisah tidur, apabila masih belum juga kembali taat, suami dibenarkan memberi pelajaran dengan jalan memukul yang tidak melukai dan tidak pada bagian muka. Kewajiban isteri terhadap suami adalah taat kepada suami serta memimpin rumah tangga suami.

Kewajiban bersama (suami isteri)

Mengenai kewajiban bersama ini ditegaskan Allah dalam firmanNya yaitu Qur'an suarat Al-Baqarah ayat 228:

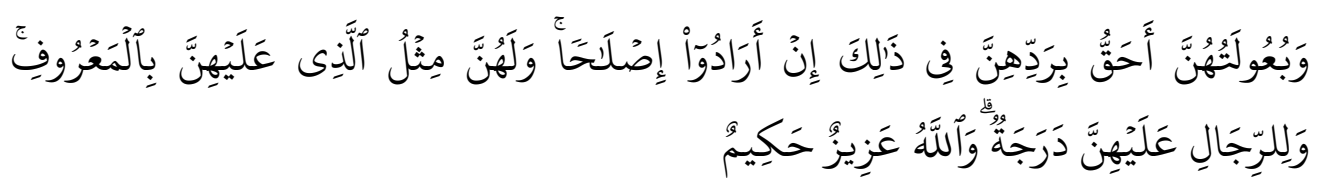

“Dan para wanita mempunyai hak yang seimbang dengan kewajibannya menurut cara yang ma'ruf". (QS. Al-Baqarah, 2: 228).

Hak dan kewajiban suami isteri diatur pula dalam Undang-Undang Perkawinan Bab VI pasal 30 sampai dengan pasal 34 dan dalam Kompilasi Hukum Islam (KHI) dalam Bab XII Pasal 77 sampai denga 84. 
Diantara hak dan kewajiban bersama salah satunya adalah memelihara anak. Anak merupakan bagian dari keluarga, karena anak adalah buah hati dan buah cinta kasih kedua orang tuanya dan anak juga merupakan amanah dari Allah yang diberikan kapada pasangannya, maka dari itu anak harus dijaga dan dirawat sebaik-baiknya.

Agam Islam yang merupakan agama terakhir dan penutup mewajibkan semau pemeluknya untuk mendidik anak sebagai generasi penerus mereka, khususnya anak-anak agar dapat hidup lebih sejahtera dan makmur di dunia dan di akhir nanti. Untuk mencapai kebahagian dunia akhir perlu pembinaan keseimbangan pendidikan antar kehidupan lahir dan kehidupan batin, jasmani dan rohani, sesuai dengan perintah Allah dan ajaran Rasulullah. Hanya dengan begini akan tercapai kemenangan di dunia dan akhir. (Baihaqi, 2001: 49).

\section{HASIL PENELITIAN DAN PEMBAHASAN}

Sejarah Berdirinya BP4

Pada umumnya menurut hukum agama perkawinan adalah perbuatan yang suci, yaitu suatu perikatan antara dua pihak dalam memenuhi perintah dan anjuran Tuhan Yang Maha Esa, agar kehidupan berkeluarga dan berumah tangga serta berkerabat tetangga berjalan baik sesuai dengan ajaran agama Islam.

Islam menempatkan perkawinan sebagai hubungan yang maha penting, semua orang diharuskan memasuki dan menyelaminya. Bahkan nabi Muhammad, melarang seseorang hidup membujang tanpa alasan apapun.

Keberadaan lembaga perkawinan adalah sarana pengembangan perasaan cinta kasih dan pengabdian diri yang diawali dlam hidup berkeluarga berkesinambungan dalam kehidupan bermasyarakat, berbangsa dan bernegara serta beragama.

Di Indonesia untuk mengembangkan, membudayakan dan memasyarakatkan makna perkawinan yang agung itu, telah didirikan Badan Penasihatan, Pembinaan dan Pelestarian Perkawinan (BP4). Badan ini didirikan pada tahun 1961 dan diresmikan pada tahun 1977 dengan keputusan Menteri Agama No 30 tahun 1977 yang menyatakan bahwa BP4 merupakan satu-satunya badan penunjang sebagian dari tugas Departemen Agama dalam hal ini Kementerian Agama dalam bidang Penasihatan, Pembinaan dan Pelestarian Perkawinan.

Menurut sejarah pertumbuhannya rganisasi ini dimulai dengan adanya organisasi BP4 di Bandung pada tahun 1954 kemudian di Jakarta dengan nama Panitia Panasehatan Perkawinan dan Penyelesaian Perceraian 
(P5). Di Jawa Tengah dan Jawa Timur dengan nama BP4 dan di Daerah Istimewah Yogyakarta dengan nama Badan Kesjahteraan Rumah Tangga (BKRT). Sebagai pelaksana keputusan konferensi Departemen Agama di Tretes Jawa Timur tanggal 25-30 Juni 1995. Maka disatukanlah organisasi tersebut dengan nama Badan Penasihatan Perkawinan dan Perceraian melalui Keputusan Menteri Agama pada tahun 1961.

Pada bulan Juni 1955 Departemen Agama di Indonesia sepakat mendirikan Badan Penasihatan Perkawinan Perselisihan dan Perceraian. Kemudian dalam Kongres Departemen Agama tahun 1961 secara nasional BP4 ditetapakan dengan KMA No. 85 tahun 1961. Melalui Keputusan Menteri Agama tahun 1977 kemudian dinyatakan bahwa BP4 merupakan satu-satunya badan penunjang dari tugas Departemen Agama dalam bidang penasihatan, perkawinan perselisihan dan perceraian.

Berdasarkan surat Keputusan Menteri Agama BP4 merupakan satusatunya organisasi semi resmi yang susunan organisasinya terorganisir dari tingkat pusat hingga ke tingkat desa/kelurahan yang tersebar di seluruh Indonesia.

Selama kiprahnya dalam penasihatan perkawinan di Indonesia ini BP4 telah mengalami perubahan nama beberapa kali. Perubahan pertama dimulai pda tahun 1972 dari Badan Penasehatan Perkawinan dan Penyelesai Perceraian yang ditetapkan pada tahun 1961, berubah nama menjadi Badan Penasehatan Perkawinan Perselisihan dan Perceraian, kemudian dengan bergulirnya reformasi pada tahun 1998 BP4 menjadi Badan Pembinaan, Penasihatan dan Pelestarian Perkawinan hingga sekarang.

Visi BP4 adalah terwujudnya keluarga sakinah, mawaddah, warahmah. Adapun misinya adalah (1) Meningkatkan kualitas konsultasi perkawinan, mediasi, dan advokasi. (2) Menigkatkan pelayanan terhadap keluarga bermasalah melalui kegiatan konseling, mediasi, dan advokasi. (3) Menguatkan kapsitas kelmbagaan dan SDM BP4 dalam rangka mengoptimalkan program dan pencapaian tujuan.

Tujuan umum berdirinya BP4 adalah untuk mempertinggi mutu perkawinan dan mewujudkan rumah tangga yang sejahtera serta kekal menurut agama Islam. Adapun tujuan khususnya adalah (a) Memberikan pelayanan yang baik kepada masyarakat. (b) Memberikan penerangan kepada masyarakat tentang upaya-upaya untuk membentuk keluarga sakinah. (c) Meningkatkan mutu penasihatan kepada calon penganten akan memasuki jenjang rumah tangga. (d) Memberikan penerangan dan nasihat mengenai nikah dan rujuk kepada yang akan melakukannya baik perorangan maupun kelompok. (e) Memberikan bantuan dalam mengatasi masalah perkawinan keluarga. (f) Memberikan bimbingan penyuluhan Undang-Undang Perkawinan serta hukum munakahat. (Anonimous, 2010:1). 
Sasaran lembaga BP\$ pada umumnya adalah (a) Terwujudnya rumah tangga bahagia setiap pasangan suami istri; dan (b) hubungan dan kerjasama yang baik dengan intansi terkait. BP4 berperan dalam penasihatan preventif, yaitu penasihatan yang dilakukan baik berupa penyluhuan, kursus-kursus dan bimbingan seperti: (a) Penyuluhan mengenai perkawinan kepada remaja usia nikah. (b) Memberikan penerangan lewat kursus bagi para calon penganten. (c) Memberikan bimbingan dalam upaya membentuk keluarga sakinah.

Lembaga ini berperan utama dalam hal penasihtan perselisihan perkawinan, yaitu penasihatan dan pengarahan yang diberikan kepada para pihak dari keluarga yang tengah menghadapi konflik keluarga. (Anonimous, 2010:1).

\section{Upaya BP4 Mewujudkan Keluarga Sakinah}

Upaya atau sosialisasi Tim BP4 dan Kepala KUA Kecamatan Cijeungjing dan P3N se-Kecamatan sebagai Kordinator P3N dan sebagai tim penggerak pembinaan keluarga sakinah adalah melalui program sebagai berikut:

\section{a. Pengajian rutin tingkat Desa}

Program pengajian rutin tingkat Desa dilakukan setiap satu minggu sekali di setiap rukun warga dengan tenaga penceramah dari pihak KUA/Penyuluh sendiri dan kyai atau ustad di wiliyah setempat. Kepala KUA membagi tugas kepada setiap penyuluh dan stafnya dengan cara membuat jadwal kegiatan rutin serta materi keagamaan, undang-undang perkawinan, serta keluarga sakinah. Materi ini juga disampaikan sebelum khutbah Jum'at.

Kenyatan bahwa ceramah keagamaan merupakan frekuensi tertinggi dalam menyampaikan penerangan khususnya mengenai keluarga sakinah yang diperoleh dari hasil wawancara dengan Kepala KUA Kecamatan Cijeungjing, maka akan mudah dipahami seberapa besar efektifitas dan kemampuan suatu acara ceramah tersebut untuk dapat menarik minat masyarakat terhadap prgram pembinaan keluarga sakinah tersebut.

\section{b. Penyuluhan oleh Kepala KUA}

Masyarakat Kecamatan Cijeungjing sangat menghormati kedudukan para ulama sebagai panutan jalan hidup yang harus dilaluinya. Hal ini dapat dilihat dari hubungan antara masyarakat dengan ulama sangatlah akrab, baik hubungan itu bersifat formal seperti di pengajian-pengajian maupun bersifat informal seperti halnya hubungan mereka sehari-hari.

Sehingga diperhatikan, jelas bahwa upaya para alim ulama sangatlah dibutuhkan. Unyuk itu dalam pelaksanaan pembinaan keluarga sakinah di 
Desa-Desa se-Kecamatan Cijeungjing melibatkan peran sertaa alim ulama, P3N dan Tokoh masyarakat.

Berdasarkan pertimbangan di atas, maka Kepala KUA Kecamatan Cijeungjig mengadakan penyuluhan kepada P3N dan tokoh masyarakat seKecamatan Cijeungjing tentang pembinaan keluarga sakinah. Penyuluhan tersebut dilakukan di KUA setiap sebulan sekali serta melaporkan hasil pembinaan yang telah dilaksanakan.

\section{c. Kunjungan pihak KUA ke Desa-Desa se-Kecamatan Cijeungjing}

Selain melakukan upaya yang telah disebutkan di atas, pihak KUA pun melakukan upaya lain, yaitu dengan melakukan kegiatan kunjungan kepada aparat Desa yang dilakukan sekitar satu smester satu kali kunjungan untuk pembinaan keluarga sakinah.

Program kunjungan ini bertujuan untuk mengetahui keadaan masyarakat Desa secara lebih dekat dilihat dari aspek kehidupan, sehingga dengan kunjungan ini diharapkan adanya kerjasama yang baik antara pihak KUA dengan pemerintahan Desa se-Kecamatan Cijeungjing dalam pembinaan keluarga sakinah. (wawancara dengan Ketua BP4, 20 Agustus 2015).

\section{d. Pedoman pembinaan keluarga sakinah}

Bagi para muda-mudi yang akan memasuki jenjang perkawinan sering menemui kesulitan-kesulitan atau hambatan-hambatan tidak saja untuk menegaskan prinsip-prinsip yang sangat asasi juga banyak faktorfaktor lain yang cukup dominan.

Oleh karena itu, tidak sedikit hubungan muda-mudi gagal membuahkan perkawinan dengan akibat-akibat yang jauh lagi. Jika suatu perkawinan gagal kebanyakan yang menjadi korban adalah pihak wanita. Tetapi juga tidak sedikit pria menjadi frustasi.

Disinilah fungsi dan peranan penasihatan sebagai upaya bantuan kepada pihak-pihak yang membutuhkannya agar tidak terjadi kegagalankegagalan yang tidak diinginkan.

Dalam tugasnya BP4 mengacu pada pedoaman penasihatan perkawinan yaitu untuk tercapainya keberhasilan penasihatan, maka sekurang-kurangnya ada lima unsur sebagai persyaratan suatu penasihatan atau bimbingan perkawinan yaitu: (a) Yang dinasihati, yaitu seorang yang membutuhkan nasihat baik pria maupun wanita, remaja ataupun dewasa yang akan melangsungkan perkwainan. (2) Masalah atau problem, yaitu kesulitan atau hambatan yang tidak dapat dipecahkan sendiri oelh individu atau pasangan calon mempelai yang bersangkutan. (3) Penasihat, perorangan ataupun badan yang melakukan bimbingan kepada individu atau pasangan yang membutuhkannya. (4) Penasihatan, yaitu upaya penasihatan atau bimbingan yang diberikan oleh para penasihat kepada 
yang dinasihati. (5) Sarana, yaitu perangkat penunjang keberhasilan penasihatan baik fisik maupun nonfisik. (Anonimous, 2002: 132).

Bentuk-bentuk penasihatan atau bimbingan perkawinan banyak tergantung kepada tujuan atau nasihat yang diinginkan oelh klien atau orang yang ingin dinasihati. Karena masalah yang dihadapi orang yang dinasihati, tidak terlalu sama bahkan tiap individu memiliki persoalan tersendiri, maka diperlukan pendekatan yang berbeda satu dengan yang lain. (Anonimos, 2002: 132).

Pendapat para Tokoh Masyarakat dan Ketua BP4 Kecamatan Cijeungiing Mengenai Kinerja BP4 dalam Mewujudkan Keluarga Sakinah

Metode dan teknik penasihatan yang dipergunakan BP4 Kecamatan Cijeungjing adalah sebagi berikut:

1) Wawancara atau Dialog khusus

Jika yang dinasihati atau klien yang minta nasihat seorang diri atau satu pasang calon pengantin maka bentuk penasihatan yang baik adalah wawancara atau dialog secara tatap muka. Wawancara semacam ini dilakukan secara tatap muka di tempat tertutup yang khusus disediakan. Bobot wawancara tergantung kepada masalah yang diajukan, ada masalah yang rumit ada pula yang sederhana. Tetapi klien sulit untuk mengemukakan hal-hal tertentu. Bahkan tidak jarang yang bersangkutan menyembunyikan hal-hal tertentu. Untuk itu penasihat harus berusaha menggali dengan pertanyaan-pertanyaan sistematik agar permasalahan terbuka.

2) Wawancara atau Dialog umum

Penasihatan seperti ini dapat dilakukan secara bersama-sama di tempat tertentu dengan metode ceramah atau tanya jawab. Sejak dilaksanakannya undang-undang perkawinan dengan memanfaatkan tenggang waktu 10 hari sebelum akad nikah di Jawa Barat beberapa KUA dengan bekerjasama dengan BP4 melaksanakan kursus perkawinan 10 hari dengan mengumpulkan beberapa pasang calo pengantin yang telah mendaftarkan kehendak nikahnya di kantor Urusan Agama (KUA) setempat.

3) Kunjungan Rumah (home-Visit)

Pada bentuk wawancara khusus sering terdapat klien yang karena sifat kasusnya khususny perlu diamati oleh penasihat lebih lanjut. Untuk itu kadangkala seorang penasihat harus datang kerumah klien yang bersangkutan dalam kunjungan rumah itu, juga karena penasihat berpendapat bahwa suatu penasihatan harus diberikan kepada keluarganya. Penasihatan atau bimbingan demikian melahirkan bentuk kunjungan rumah (home-visit). Sekarang ini kunjungan rumah menjadi 
suatu metode efektif untuk memberikan secara motivatif tanpa melihat ada atau tidak ada kasusnya. Dengan kunjungan rumah tersebut banyak pesan yang dapat disampaikan oleh penasihat untuk memotivasi tujuan rumah tangga bahagia sejahtera. (Aninomuos, 2002: 143).

Adapun materi penasihatan yang disampaikan BP4 harus disesuaikan dengan klien yang bersangkutan. Materi harus berkembang dan disesuaikan kemajuan perkembangan masyarakat.

Dengan demikian bahwa program pembinaan keluarga sakinah yang dilakukan oleh tim BP4 dan Pihak KUA Kecamatan Cijeungjing sangat didukung oleh masyarakat, itu dapat dilihat dari jawaban mereka terhadap keluarga sakinah itu berbeda-beda, intinya sama menjalin hubungan suami siteri yang harmonis, itu dikarenakan pemberian materi yang berbeda-beda cara penyampaiannya namun tujuan sama, jadi pemahaman mereka juga berbeda-beda.

Masayarakat sangat mendukung dan ikut berpartisipasi terusmenerus dalam program pembinaan mengartikan kelaurga sakinah menurut mereka adalah keluarga yang merasakan keharmonisan rumah tangga dengan ketenangan hati dan ketentraman jiwa yang dikarenakan terjalinnya hubungan suami isteri yang harmonis, hubungan antara orang tua dengan anak yang saling menyayangi serta saling menghormati dan hubungan antara keluarga secara umum juga tampak tenang, tanpa ada pengaruh ekonomi, pendidikan anak dan tingkat kesadaran keagamaan anggota dalam rumah tangga nyaman.

\section{Kiat-kiat dalam Menuju Keluarga Sakinah BP4}

Agama Islam telah memberikan petunjuk yang lengkap dan rinci terhadap persoalan pernikahan. Mulai dari anjuran menikah, cara memilih pasangan yang ideal, melakukan khitbah (peminangan), bagaimana mendidik anak, serta memberikan jalan keluar jika terjadi kemelut dalam rumah tangga, sampai dalam proses nafaqah (memberi nafkah) dan harta waris, semua diatur oleh Islam secara rinci, detail dan gamblang.

Selanjutnya untuk memahami konsep pernikahan dalam Islam, maka rujukan yang paling benar dan sah adalah Al Qur'an dan As Sunnah Ash Shahihah yang sesuai dengan pemahaman Salafush Shalih. Berdasar rujukan ini, kita akan memperoleh kejelasan tentang aspek-aspek pernikahan, maupun beberapa penyimpangan dan pergeseran nilai pernikahan yang terjadi di dalam masyarakat kita.

Pernikahan adalah fitrah kemanusiaan, maka dari itu Islam menganjurkan untuk menikah, karena nikah merupakan gharizah insaniyah (naluri kemanusiaan). Allah berfirman: 


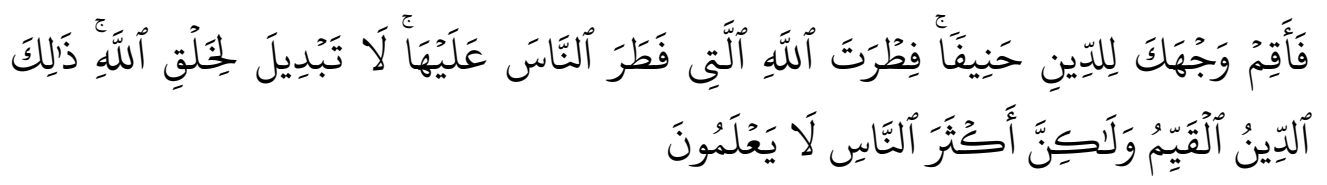

Maka hadapkanlah wajahmu dengan lurus kepada agama (Allah), (tetaplah atas) fitrah Allah yang telah menciptakan manusia menurut fitrah itu. Tidak ada perubahan pada fitrah Allah. (Itulah) agama yang lurus; tetapi kebanyakan manusia tidak mengetahui. (Ar Ruum: 30:30).

Islam Menganjurkan Nikah Penghargaan Islam terhadap ikatan pernikahan besar sekali, Allah menyebutkan sebagai ikatan yang kuat, Allah berfirman:

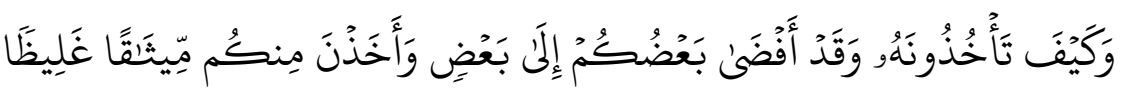

Dan mereka (isteri-isterimu) telah mengambil dari kamu perjanjian yang kuat. (An Nisaa, 4: 21).

Tujuan pernikahan dalam Islam adalah (a) Untuk memenuhi tuntutan naluri manusia yang asasi pernikahan adalah fitrah manusia, maka jalan yang sah untuk memenuhi kebutuhan ini adalah dengan aqad nikah (melalui jenjang pernikahan), bukan dengan cara yang kotor dan menjijikan, seperti cara-cara orang sekarang ini dengan berpacaran, kumpul kebo, melacur, berzina, lesbi, homo, dan lain sebagainya yang telah menyimpang dan diharamkan oleh Islam. (b) Untuk membentengi akhlaq yang mulia. (c) Untuk menegakkan rumah tangga yang islami.

Jadi tujuan yang luhur dari pernikahan adalah agar suami isteri melaksanakan syari'at Islam dalam rumah tangganya. Hukum ditegakkannya rumah tangga berdasarkan syari'at Islam adalah wajib. Oleh karena itu, setiap muslim dan muslimah harus berusaha membina rumah tangga yang Islami. Ajaran Islam telah memberikan beberapa kriteria tentang calon pasangan yang ideal, agar terbentuk rumah tangga yang Islami. Di antara kriteria itu ialah harus kafa'ah dan shalihah.

Kafa'ah Menurut konsep Islam kafa'ah (setaraf, sederajat) menurut Islam hanya diukur dengan kualitas iman dan taqwa serta akhlaq seseorang, bukan diukur dengan status sosial, keturunan dan lain-lainnya. (a) Untuk meningkatkan ibadah kepada Allah. (b) Untuk memperoleh keturunan yang shalih.

Ada sebagian kaum muslimin yang telah menikah dan dikaruniai oleh Allah seorang anak atau dua orang anak, kemudian mereka membatasi kelahiran, tidak mau mempunyai anak lagi dengan berbagai alasan yang tidak syar'i. Perbuatan mereka telah melanggar syari'at Islam. Fatwa-fatwa ulama Ahlus Sunnah Wal Jama'ah telah menjelaskan dengan tegas, bahwa 
membatasi kelahiran atau dengan istilah lainnya "keluarga berencana", hukumnya adalah haram.

Sesungguhnya banyak anak itu banyak manfaatnya. Di antara manfaat dengan banyaknya anak dan keturunan, adalah:

1) Di dunia mereka akan saling menolong dalam kebajikan.

2) Mereka akan membantu meringankan beban orang tuanya.

3) Do'a mereka akan menjadi amal yang bermanfaat ketika orang tuanya sudah tidak bisa lagi beramal (telah meninggal dunia).

4) Jika ditaqdirkan oleh Allah Subhanahu wa Ta'ala anaknya meninggal ketika masih kecil, insya Allah, ia akan menjadi syafa'at (penolong) bagi orang tuanya nanti di akhirat.

5) Anak akan menjadi hijab (pembatas) dirinya dengan api neraka, manakala orang tuanya mampu menjadikan anak-anaknya sebagai anak yang shalih dan shalihah.

6) Dengan banyaknya anak, akan menjadikan salah satu sebab bagi kemenangan kaum muslimin ketika dikumandangkan jihad fi sabilillah, karena jumlahnya yang sangat banyak.

7) Rasulullah Shallallahu 'alaihi wa sallam bangga dengan jumlah umatnya yang banyak. Apabila seorang muslim cinta kepada Rasulullah Shallallahu 'alaihi wa sallam, maka hendaklah ia mengikuti keinginan Rasulullah Shallallahu 'alaihi wa sallam untuk memperbanyak anak, karena Beliau Shallallahu 'alaihi wa sallam bangga dengan banyaknya ummatnya pada hari kiamat.

Bila belum dikaruniai anak, apabila ditaqdirkan Allah, sepasang suami-isteri sudah menikah sekian lama, namun belum juga dikaruniai anak, maka janganlah ia berputus asa dari rahmat Allah. Hendaknya ia terus berdo'a sebagaimana Nabi Ibrahim dan Zakaria telah berdo'a kepada Allah, sampai Allah, mengabulkan do'a mereka, dan hendaknya bersabar dan ridha dengan qadha' dan qadar yang Allah tentukan, serta meyakini bahwa semua itu ada hikmahnya.

Faktor Penghambat dan Pendorong Upaya BP4 Mewujudkan Kelurga Sakinah di Kecamatan Cijeungjing

Untuk dapat melaksanakan visi dan misinya maka BP4 memiliki program-program untuk dijalankan. Adapun program-program yang telah dijalankan oleh BP4 Kabupaten Jepara yang terbagi dalam bidang-bidang, sebagai berikut:

a. Bidang pendidikan keluarga sakinah dan pengembangan SDM

1) Menyempurnakan buku pedoman pelaksanaan pendidikan keluarga sakinah 
2) Mengadakan pendidikan keluarga sakinah sebagai upaya pemahaman keimanan dan ketaqwaan

3) Menyiapkan kader motivator keluarga sakinah

4) Menyempurnakan modul dan bahan ajar

5) Menyelenggarakan kursus calon pengantin, pendidikan dan pelatihan tenaga dan petugas korps penasihatan dan pembinaan pendidikan keluarga sakinah.

b. Bidang Konsultasi perkawinan dan keluarga

1) Meningkatkan pelayanan konsultasi hukum, penasihatan perkawinan dan keluarga disetiap tingkat organisasi

2) Mengupayakan rekrutmen tenaga profesional di bidang psikologi, agama, hukum, pendidikan, sosiologi dan antropologi

3) Menyusun pola pengembangan SDM yang terkait dengan pelaksanaan kegiatan BP4

4) Menyelenggarakan konsultasi jodoh

5) Menyelenggarakan praktek konsultasi perkawinan dan keluarga melalui telepon dalam saluran khusus, TV, radio, media cetak dan media elektronika lainnya

6) Meningkatkan kerjasama dengan lembaga lain yang bergerak pada bidang penasihatan perkawinan dan keluarga

7) Menerbitkan buku kasus perkawinan dan keluarga

c. Bidang Penerangan

1) Mengadakan diskusi, ceramah, seminar/temu karya dan kursus serta penyuluhan tentang: (a) Pembinaan keluarga sakinah. (b) Undang-undang, Perkawinan, Hukum Munakahat, Kompilasi Hukum Islam. (c) Pendidikan keluarga sakinah.

2) Meningkatkan kegiatan penerangan dan motivasi pembinaan keluarga sakinah melalui media cetak, media elektronika, tradisional, tata muka, percontohan/keteladanan.

3) Mengusahakan agar majalah perkawinan dan keluarga dapat disebarluaskan kepada masyarakat

4) Meningkatkan perpustakaan BP4 ditingkat pusat dan daerah

d. Bidang Penelitian dan pengembangan

1) Melakukan penelitian tentang kasus-kasus perkawinan dan keluarga 
2) Mengadakan penelitian tentang perubahan tatanan nilai sosial dan pengaruhnya terhadap kehidupan perkawinan dan keluarga bekerjasama dengan Badan Litbang Departemen Agama atau pihak lain yang relevan.

3) Mengupayakan pengembangan metode dan sistem yang lebih cepat dalam rangka meningkatkan mutu penasihatan perkawinan dan pendidikan keluarga sakinah

4) Mengadakan evaluasi dan penilaian keberhasilan BP4

e. Bidang Pembinaan keluarga sakinah

1) Melakukan advokasi di berbagai bidang dan upaya mewujudkan keluarga sakinah

2) Mengadakan pembinaan terhadap keluarga sakinah di semua tingkatan

3) Menyusun dan menetapkan konsep dasar kriteria dan prosedur pemilihan keluarga sakinah

4) Melakukan pembentukan desa binaan sebagai pilot proyek $d$ seluruh propinsi dan masing-masing propinsi diharapkan memiliki minimal 2 setiap kecamatan

5) Menjalin kerjasama dengan Pemerintah Daerah, Kantor Kependudukan/BKKBN dan instansi terkait lainnya dalam penyelenggaraan dan pendanaan pemilihan keluarga sakinah teladan

6) Menyelenggarakan pemilihan dan pengukuhuan keluarga sakinah teladan tingkat nasional setiap tahun

7) Menerbitkan buku tentang keluarga sakinah teladan tingkat nasional

f. Bidang Usaha

1) Mengupayakan alokasi anggaran dari DIKS NR, APBN dan APBD untuk mendukung program BP4 di pusat dan daerah

2) Membentuk badan usaha BP4 yang bergerak dalam bidang jasa, perdagangan atau industri

3) Melakukan usaha produktif untuk meningkatkan kemampuan keuangan dan anggaran organisasi

4) Memberdayakan ekonomi keluarga

BP4 Kecamatan Cijeungjing dalam menjalankan tugasnya masih banyak terdapat hambatan yang dihadapinya. Faktor penghambat tersebut bukan dikarenakan mutu dari BP4 Kecamatan Cijeungjing, tetapi 
masyarakat yang tidak banyak menggunakan jasa pelayanan konsultasi BP4, belum optimalnya pelaksanaan tugas penasihatan dan pembinaan keluarga serta masih lemahnya hubungan atau koordinasi dengan instansi pemerintah dan lembaga-lembaga kemasyarakatan. Selain itu juga ada beberapa faktor pendorong keberhasilan pelaksanaan program kerja BP4 sebagai berikut ; besarnya dukungan moril dari masyarakat terhadap pembentukan keluarga sakinah, besarnya dukungan moril instansi pemerintah, lembaga kemasyarakatan nasional dan internasional, dukungan para pakar terdapat terhadap upaya penasihatan perkawinan dan pembinaan keluarga serta kesediaan masyarakat untuk meniru dan meneladani sikap dan tingkah laku keluarga sakinah yang dipilih melalui pemilihan keluarga sakinah.

\section{KESIMPULAN}

Dari pembahasan dan analisis yang dikaji dalam bab-bab sebelumnya, dapat ditarik beberapa kesimpulan, yaitu: (a) Upaya BP4 mewujudkan keluarga sakinah, yaitu melakukan pengajian rutin tingkat Desa, penyuluhan oleh Kepala KUA, kunjungan pihak KUA ke Desa-Desa dan pembinaan keluarga sakinah dengan para klien. (b) Kiat-kiat menuju keluarga sakinah, untuk memenuhi tuntutan naluri manusia yang asasi pernikahan adalah fitrah manusia, untuk membentengi akhlaq yang mulia, untuk menegakkan rumah tangga yang Islami, untuk meningkatkan ibadah kepada Allah dan untuk memperoleh keturunan yang shalih. (c) Faktor penghambat dan pendorong Upaya BP4 adalah bidang pendidikan keluarga sakinah dan pengembangan SDM, Bidang Konsultasi perkawinan dan keluarga, bidang penerangan, bidang penelitian dan pengembangan, bidang Pembinaan keluarga sakinah, dan bidang usaha.

\section{DAFTAR PUSTAKA}

Al-Utsaimin, M. Saleh dan A. Aziz Muhammad Daud. (1991). Pernikahan Islami Dasar Hukum Hidup Berumah Tangga,. Risalah Gusti.

Anonimous. (2011). Kompilasi Hukum Islam. Penerbit Citra Umbara, Bandung.

Asmawim Muhammad. (2004). Nikah Dalam Perbincangan dan Perdebaikan, cet. Ke -1, Darussalam. Yogyakarta.

Badan Penasihatan, Pembinaan dan Pelestarian Perkawinan (BP4), Hasil Munas Ke XI, 1998. BP4 Pusat. Jakarta.

BP4. (2001). Buku Pintar Keluarga Muslim, Depag Jawa Tengah. Semarang.

BP4. (1997). Pedoman Pembinaan Keluarga Sakinah. Semarang. 
Dachlan Aijah Nj. (1969). Membina Rumah Tangga Bahagia dan Peranan Agama Dalam Rumah Tangga. Jamunu. Jakarta.

Daradjat Zakiah. (1995 ). Ilmu Figh, II. PT. Dana Bhakti Wakaf. Yogyakarta.

Data BP4 Kabupaten Ciamis Tahun 2009.

Depag RI. (1998). Al Qur'an dan Terjemahannya,. Mujamma' al Malik Fahd li Thibo'at al mushhaf asy-Syarif. Madinah.

Departemen Agama Provinsi Jawa Tengah. (2001) Buku Pintar Keluarga Muslim, Semarang,

Direktorat Jendral Bimbingan Masyarakat Islam dan Penyelenggaraan Haji Proyek Peningkatan Tenaga Keagamaan. (2003) Pedoman Pelaksanaan Akad Nikah, Jakarta.

Ghazaly Abdul Rahman, H., (2006). Fiqh Munakahat. Kencana Prenada Media Group. Jakarta.

Hasil Munas BP4 XIII/2004 dan Pemilihan Keluarga Sakinah Teladan Tingkat Nasional , Jakarta: BP4, 2005

Imam, Kam. (2013). Fadhilah Tahajjud Untuk Menciptakan Keluarga Sakinah. Penerbit Diva Press, Jogjakarta.

Kuzari Ahmad, (1995). Nikah Sebagai Perikatan. PT Raja Grafindo Persada. Jakarta.

Latif H.S.M. Nasaruddin. (2001). Ilmu Perkawinan Problematika Seputar Keluarga dan Rumah Tangga. Pustaka Hidayah. Jakarta.

LPP IAID. (2014). Panduan Penyusunan Skripsi di Lingkungan institusi Agama Islam Darussalam, Ciamis.

Majalah bulanan. (2002). Perkawinan dan keluarga, t.p, Jakarta.

Moleong Lexy J., (2004). Metode Penelitian Kualitatif, Edisi Revisi, PT Remaja Rosdakarya. Bandung.

Muhadjir Noeng, (2002). Metodologi Penelitian Kualitatif, edisi IV, cet. II, Rake Sarasin. Yogyakarta.

Mukhtar Kamal. (2002). Asas-asasa Hukum Islam Tentan Perkaawinan, cet ke-3. Bulan Bintang. Jakarta.

Nasution Khoirudin. (2005). Hukum Perkawinan I: Dilengkapi Perbandingan UU Negara Muslim Komtemporer. ACAdeMIA \& TAZZAFA. Yogyakarta.

Nuruddin Amir H., (2004). Hukum Perdata Islam. Prenada Media. Jakarta.

Salam, Lubis. t.t. Menuju Keluarga Sakinah. Terbit Terang, Surabaya. 